\title{
Kisspeptin and energy balance in reproduction
}

\author{
Julie-Ann P De Bond and Jeremy T Smith \\ School of Anatomy, Physiology and Human Biology, M309, The University of Western Australia, Hackett Entrance 2, \\ Hackett Drive, Nedlands, Perth, Western Australia 6009, Australia
}

Correspondence should be addressed to J T Smith; Email: jeremy.smith@uwa.edu.au

\begin{abstract}
Kisspeptin is vital for the neuroendocrine regulation of GNRH secretion. Kisspeptin neurons are now recognized as a central pathway responsible for conveying key homeostatic information to GNRH neurons. This pathway is likely to mediate the well-established link between energy balance and reproductive function. Thus, in states of severely altered energy balance (either negative or positive), fertility is compromised, as is Kiss 1 expression in the arcuate nucleus. A number of metabolic modulators have been proposed as regulators of kisspeptin neurons including leptin, ghrelin, pro-opiomelanocortin (POMC), and neuropeptide Y (NPY). Whether these regulate kisspeptin neurons directly or indirectly will be discussed. Moreover, whether the stimulatory role of leptin on reproduction is mediated by kisspeptin directly will be questioned. Furthermore, in addition to being expressed in GNRH neurons, the kisspeptin receptor (Kiss1r) is also expressed in other areas of the brain, as well as in the periphery, suggesting alternative roles for kisspeptin signaling outside of reproduction. Interestingly, kisspeptin neurons are anatomically linked to, and can directly excite, anorexigenic POMC neurons and indirectly inhibit orexigenic NPY neurons. Thus, kisspeptin may have a direct role in regulating energy balance. Although data from Kiss1r knockout and WT mice found no differences in body weight, recent data indicate that kisspeptin may still play a role in food intake and glucose homeostasis. Thus, in addition to regulating reproduction, and mediating the effect of energy balance on reproductive function, kisspeptin signaling may also be a direct regulator of metabolism.

Reproduction (2014) 147 R53-R63
\end{abstract}

\section{Kisspeptin governs puberty onset and reproduction}

Kisspeptin is a hypothalamic neuropeptide that drives fertility by stimulating gonadotropin-releasing hormone (GNRH) neurons (Gottsch et al. 2004, Han et al. 2005). A product of the KISS1 gene, kisspeptin, is cleaved from an initial 145 amino acid precursor to a 54 amino acid peptide in humans (Kotani et al. 2001, Ohtaki et al. 2001) and a 52 amino acid peptide in mice (Terao et al. 2004). In humans, smaller isoforms of 14 and 13 amino acids have also been isolated, each sharing the common C-terminal sequence (Kotani et al. 2001, Ohtaki et al. 2001). Kisspeptin binds to the once orphaned G-proteincoupled receptor-54 (Kotani et al. 2001), now commonly referred to as Kiss1r (Gottsch et al. 2009).

Two independent research groups discovered the essential role of kisspeptin in reproduction almost simultaneously in 2003, when Kiss1r mutations were isolated in cases of idiopathic hypogonadotropic hypergonadism (de Roux et al. 2003, Seminara et al. 2003). Seminara et al. (2003) were also the first to examine Kiss $1 r$ null mice, which shared the infertility and had no other discernible phenotype. It is now universally accepted that kisspeptin is fundamental to GNRH-driven fertility and the key pieces of evidence for this include the following: i) the stimulatory effect of kisspeptin is blocked by GNRH antagonists (Gottsch et al. 2004, Irwig et al. 2004, Matsui et al. 2004, Shahab et al. 2005); ii) injections of kisspeptin directly in to the vicinity of GNRH neuron stimulate luteinizing hormone (LH) secretion (Patterson et al. 2006); iii) kisspeptin activates GNRH neurons in vivo (Irwig et al. 2004, Matsui et al. 2004) and in vitro (Han et al. 2005, Pielecka-Fortuna et al. 2008); iv) kisspeptin immunoreactive fibers appose GNRH neuron cell bodies (Kinoshita et al. 2005, Clarkson \& Herbison 2006, Smith et al. 2008) and their terminals within the median eminence (Smith et al. 2011); v) kisspeptin stimulates GNRH release into the portal circulation of sheep (Smith et al. 2011) and the isolated mediobasal hypothalamus (d'Anglemont de Tassigny et al. 2008); and finally vi) almost all GNRH neurons express Kiss1r (Irwig et al. 2004, Han et al. 2005, Smith et al. 2009). Importantly, the effects of kisspeptin are absent in Kiss1r knockout (KO) mice, showing specificity to this receptor (Messager et al. 2005, Dungan et al. 2007, Kauffman et al. 2007).

It is worthy to note that using a genetic ablation approach, the importance of the kisspeptin system in mice has been challenged. Mice with ablated kisspeptin neurons presented with normal fertility 
(Mayer \& Boehm 2011). However, it is questionable whether a complete loss of kisspeptin cells was achieved. It is likely that this result reflects redundancy in kisspeptin neurons and signaling as genetically targeted mice with 50 and $95 \%$ reductions in Kiss 1 transcript still maintain, albeit impaired in females, fertility (Popa et al. 2013). In addition, the DBA/2J mouse strain possess less than one-tenth the level of Kiss1 mRNA in the brain than the C57BL/6 mice (Quennell et al. 2011), yet are fertile. Thus, these data may highlight the importance of kisspeptin in reproduction, in that it is synthesized in excess to ensure reproductive success.

One of the primary functions of kisspeptin appears to be as an interneuronal bridge between systemic levels of sex steroids and GNRH neuron regulation (Smith 2013; Fig. 1). In rodents, kisspeptin-producing cells are found in the anteroventral periventricular nucleus (AVPV) and the arcuate nucleus (ARC) (Smith 2013). In sheep, kisspeptin neurons are located in the dorsolateral region of the preoptic area (POA) (perhaps a homologous population to the rodent AVPV) and the ARC (Estrada et al. 2006, Smith et al. 2007), and estrogen regulation of kisspeptin has been extensively studied in these regions in both rodents and sheep (Smith 2013). Both neuronal populations are important in the generation of estrogenpositive feedback and sex steroid-negative feedback signals to GNRH neurons. The former, critical for the GNRH/LH surge and ovulation in females and the latter, involved in the tonic/pulsatile regulation of GNRH secretion in both sexes (Simerly 2002, Herbison 2008). Specifically, sex steroids robustly regulate kisspeptin neurons and those in the ARC forward signals applicable to negative feedback regulation of GNRH in mice (Smith et al. 2005a, 2005b). In the female rodent,

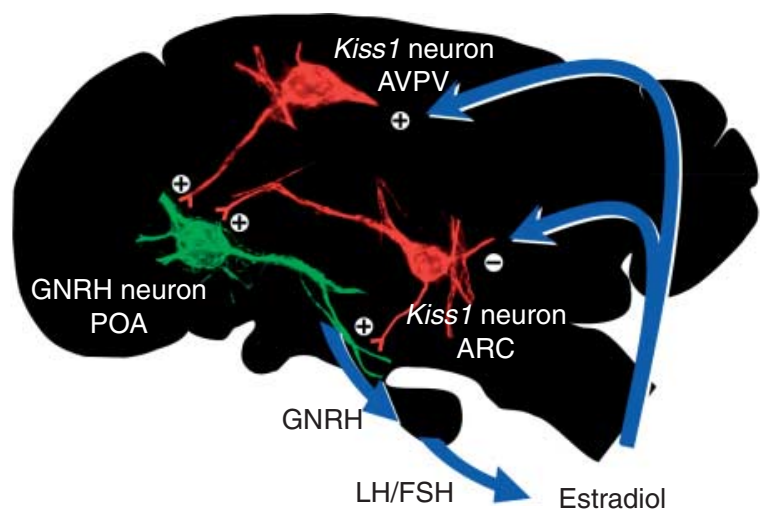

Figure 1 The proposed negative and positive feedback mechanism exerted by ovarian steroids on the regulation of kisspeptin neurons. In rodents, Kiss 1 neurons are located in both AVPV and ARC and stimulate (+) GNRH neurons. In the ARC, Kiss1 neurons project directly to GNRH cell bodies and their terminals in the median eminence. Moreover, estradiol $\left(E_{2}\right)$ inhibits (-) ARC Kiss1 neurons consistent with negative feedback control of GNRH neurons. In the AVPV, $E_{2}$ stimulates (+) Kiss 1 neurons, facilitating positive feedback regulatory control and the preovulatory GNRH/LH surge. AVPV Kiss1 neurons only project directly to GNRH cell bodies.
AVPV kisspeptin cells are critical for positive feedback regulation of GNRH (Smith et al. 2005a, 2006b). In sheep, key differences are apparent in feedback regulation of GNRH compared with rodents. Thus, estradiol $\left(E_{2}\right)$-induced positive feedback appears to be mediated by kisspeptin neurons in both the ARC (Estrada et al. 2006, Smith et al. 2009) and the POA (Smith et al. 2009, Hoffman et al. 2011).

\section{Metabolic control of fertility}

The appropriate regulation of energy balance is important for fertility. Successful reproduction requires adequate resources within the individual organism. Thus, the ability to control reproduction and metabolism simultaneously ensures that offspring are born into an environment with sufficient energy supplies to maintain survival of both the mother and the offspring (Evans \& Anderson 2012). As a result, there is a clear association of the effects of energy balance on reproduction, whereby perturbations in energy balance, including obesity and frequently result in fertility impairment (Pasquali et al. 2007). In most cases, it is evident that negative energy balance, when less energy (food) is consumed than is expended in metabolism, inhibits the reproductive axis. Ewes subjected to restricted feeding exhibited a significant decrease in mean $\mathrm{LH}$ concentration, $\mathrm{LH}$ pulse frequency, and follicle-stimulating hormone ( $\mathrm{FSH}$ ) concentrations compared with normal fed ewes (Thomas et al. 1990). In male rats, food restriction decreased $\mathrm{LH}, \mathrm{FSH}$, and testosterone levels compared with ad libitum fed controls (Compagnucci et al. 2002). Similar studies are also evident in mice, showing reduced fertility as a consequence of undernutrition (Castellano et al. 2005, Luque et al. 2007). Overall, these studies demonstrate that lean animals with a reduced food intake are often hypogonadotropic.

At the other end of the metabolic spectrum, dietinduced obesity (DIO) also has an effect on reproductive status. This is especially relevant now because obesity is reaching epidemic proportions and is one of the most serious public health issues facing the developed world. In male mice with $\mathrm{DIO}$, sperm motility and fertility are compromised compared with normal-weight controls (Ghanayem et al. 2010). In adult female DBA/2J mice, which are susceptible to DIO, there were decreases in pregnancy rates and GNRH expression compared with controls (Tortoriello et al. 2004). These studies highlight that obesity can also lead to reduced fertility.

\section{The effect of energy status on fertility is mediated by kisspeptin}

As both metabolic state and energy balance are important for reproduction, it would be reasonable to assume that kisspeptin neurons can provide the link 
between energy status and fertility. The role of kisspeptin expression in altered energy states has been investigated in states of undernutrition in mice and streptozotocininduced diabetes in rats. Fasting in prepubertal rats led to a significant reduction in whole hypothalamic Kiss 1 but increased Kiss1r expression compared with normal fed rats (Castellano et al. 2005). Using a shorter period of fasting (48 h) in adult male mice, both Kiss1 and Kiss1r mRNA expression was reduced compared with fed controls (Luque et al. 2007). In a different altered energy state, an induced diabetic rat model, there was a significant decrease in Kiss1 mRNA compared with controls (Castellano et al. 2006). In follow-up studies isolating the distinct populations of Kiss 1, fasting reduced expression in the AVPV, but not the ARC, in adult female ovariectomized (OVX) rats (Kalamatianos et al. 2008). Alternatively, chronic calorie restriction in female rats at the age of puberty reduced Kiss 1 expression in the ARC, but not the AVPV (Roa et al. 2009). In OVX ewes, the effect of body weight status was seen on Kiss1 mRNA expression in both the ARC and the rostal, POA region, and was reduced in ewes made lean (Backholer et al. 2010). Thus, both populations of kisspeptin neurons are potential targets for negative energy balance.

To further support the role of kisspeptin in mediating the effects of energy status on fertility, there are functional data where exogenous kisspeptin administration can rescue the hypothalamic-pituitary axis in these conditions. Fasted prepubertal male and female rats showed a significant increase in LH levels when they were centrally administrated with kisspeptin (Castellano et al. 2005). Furthermore, in a male diabetic rat model, kisspeptin administration led to a significant increase in LH levels compared with a vehicle control (Castellano et al. 2006). Thus, in conditions of negative energy balance, treatment with kisspeptin may overcome the reduced endogenous expression of Kiss 1 and rescue any deficit in reproductive function. Alternatively, such a relationship does not automatically preclude a role for kisspeptin in mediating the effects of energy status. Kisspeptin may simply bypass the neuronal pathways that exert inhibitory metabolic actions on GNRH secretion, thus the data above should be considered with caution.

With regard to positive energy balance, data are relatively scarce. However, in one recent study, Kiss 1 expression was investigated in a DIO mouse model. Here, female DBA/2J mice made obese by maintenance on a high-fat diet from weaning to adulthood had reduced Kiss 1 mRNA in the ARC and the AVPV compared with chow-fed controls. Consistent with this, kisspeptin neuron number (as detected by immunohistochemistry) was also reduced in the latter (Quennell et al. 2011).

From the aforementioned data, it is clear that energy balance has profound effects on the reproductive axis and these appear to be mediated, at least in part, by kisspeptin expression and signaling in the hypothalamus.
This immediately raises the question as to what metabolic signals govern this effect. Metabolic control involves multiple factors acting on and within the hypothalamus (Barsh \& Schwartz 2002), and it is possible that any one or the combined effect of many signals is important for the regulation of kisspeptin and in turn fertility.

\section{Metabolic regulators of kisspeptin}

\section{Leptin}

The adipose hormone leptin is a critical component for energy balance. Leptin is secreted in proportion to fat stores and acts within the brain to signal adequate energy stores and satiety (Halaas et al. 1995). Adequate leptin concentrations are also known to be essential for the reproductive axis, gating the onset of puberty (Cheung et al. 1997, Chehab 2000) again through action in the brain (de Luca et al. 2005). Despite the acceptance of leptin as a requisite for puberty and fertility, the neuroanatomical pathway linking leptin signaling to GNRH neurons is not yet fully understood. GNRH neurons do not possess the signaling isoform of the leptin receptor (LepRb; Quennell et al. 2009). Therefore, interneuronal pathways that are sensitive to leptin and converge on GNRH neurons are required and kisspeptin neurons are recognized as a primary candidate.

We were the first to demonstrate leptin's regulatory control of the kisspeptin system using leptin-deficient ob/ob mice (Smith et al. 2006a). Owing to the lack of circulating leptin, these mice are obese but experience a condition of perceived negative energy balance and are infertile. Male $o b / o b$ mice had significantly reduced expression of Kiss 1 mRNA in the ARC compared with WT littermates and this was partially corrected when exogenous leptin was administered to the periphery. Importantly, all mice in this study were castrated to remove the confounding regulatory effects of endogenous gonadal steroids, which are reduced in $o b / o b$ mice. The study also confirmed the presence of Lepr (LepRb) mRNA on $40 \%$ of kisspeptin neurons in the ARC, indicating that leptin regulation of gene expression is likely to occur directly on kisspeptin neurons (Fig. 2).

In support of this study, female $o b / o b$ mice were also shown to have reduced expression of Kiss 1 mRNA in the ARC compared with WT controls (Quennell et al. 2011). Moreover, this reduction was again shown in OVX mice and also in OVX mice with baseline estrogen replacement (Quennell et al. 2011). Similar confirmation of leptin regulation of kisspeptin has been reported in rats using a streptozotocin-induced diabetes model (resulting in hypoinsulinemia and hypoleptinemia; Castellano et al. 2006). Here, central leptin administration was able to restore the otherwise reduced expression of Kiss 1 mRNA in the whole hypothalamus. In guinea pigs, leptin can induce depolarization of kisspeptin neurons in the 


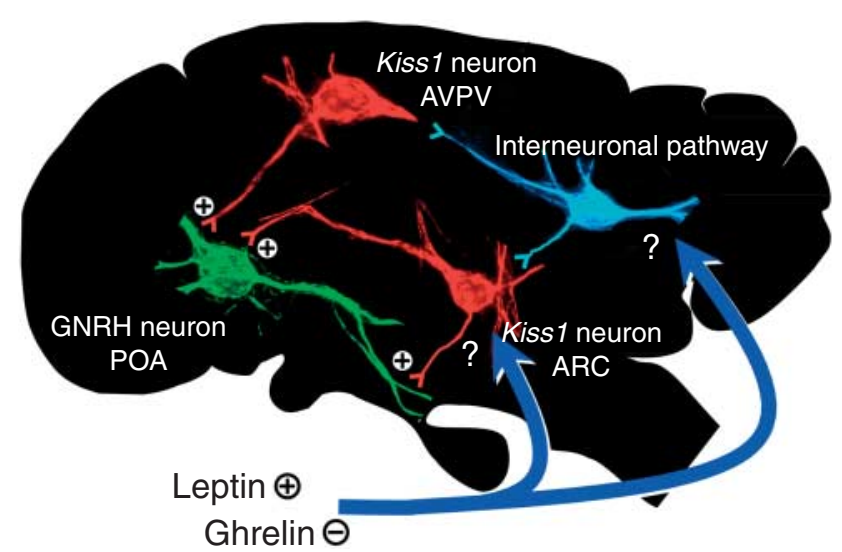

Figure 2 The potential role of leptin and ghrelin on Kiss1 neuron regulation. Leptin stimulates (+) Kiss1 expression in both AVPV and ARC, but direct or indirect action on Kiss1 neurons is currently debated (?). Data suggest a direct role on ARC Kiss1 neurons, but not those in the AVPV. Equally, data show an interneuronal pathway linking leptin signaling to Kiss 1 neurons. Alternatively, ghrelin inhibits (-) Kiss 1 neurons and does so in the AVPV via a yet to be determined indirect mechanism (?). There is currently no evidence to claim a direct action of ghrelin on ARC Kiss1 neurons (?), but this remains a possibility.

ARC, of which 36\% express Lepr (Qiu et al. 2011). Finally, similar data are also apparent in sheep. In OVX ewes made lean through dietary restriction, reduced Kiss 1 expression in the ARC was again partially restored with central leptin administration (Backholer et al. 2010). Interestingly, in this study, a similar effect was also observed in the POA kisspeptin neurons and virtually all these neurons (both POA and ARC) expressed Lepr mRNA (Backholer et al. 2010).

Despite the evidence for a direct effect of leptin on kisspeptin neurons, more recent discoveries have cast doubt as to whether this is indeed the case. Subsequent neuroanatomical data in female sheep show a complete absence of leptin-induced pSTAT3 responses (indicating the presence of functional LepR) in either POA or ARC kisspeptin neurons (Louis et al. 2011). This same publication also showed an absence of LepRb (detected using Lepr-EGFP transgenic mice) in immunoreactive kisspeptin neurons in the AVPV. Moreover, a very limited proportion (0-6\%) of ARC kisspeptin neurons (visualized using Tac2-EGFP transgenic mice) coexpressed pSTAT3 immunoreactivity (Louis et al. 2011). In this model, however, the number of 'kisspeptin neurons' visualized via Tac2-EGFP appeared limited and so it is conceivable that the authors may have underestimated this population and reduced their ability to detect LepRb colocalization. Indeed, other studies using similar techniques have shown leptin activation (pSTAT3) in $15 \%$ of ARC kisspeptin neurons (Cravo et al. 2011). Despite this, the notion of kisspeptin neurons receiving direct input from leptin signaling has certainly become a contentious one. This was originally brought to the fore in a paper demonstrating that the onset of puberty is unaltered in a female mouse model with a targeted disruption of LepR selectively in Kiss1 neurons (Donato et al. 2011). Of interest here is that functional LepR signaling (pSTAT3 immunoreactivity) was confirmed in $13-20 \%$ of ARC kisspeptin neurons in control (Lep $\left.R^{\text {flox/flox }}\right)$ mice. As predicted, receptor expression was markedly reduced, but not completely abolished, in Kiss1-Cre LepR $R^{\text {flox/flox }}$ mice. So it is possible that the remaining (but severely limited) LepR expression on kisspeptin neurons following cre-lox recombination may still be adequate for the relay of leptin signaling to kisspeptin neurons and in-turn fertility. Of note here is the apparent redundancy in Kiss 1 expression required for fertility in mice (Popa et al. 2013). Equally, it is noted in Kiss1-Cre LepR $R^{\text {flox fllox }}$ mice that LepR deletion was also apparent in the ovary and testes (Donato et al. 2011). Kiss 1 expression has been documented in the gonads (Gaytan et al. 2009, Tariq et al. 2013) and also other brain regions during development (Gottsch et al. 2011), so the specificity of LepR deletion may be compromised. This, paired with the possibility of developmental compensatory mechanisms in the transgenic model, should not be ignored. In order to overcome many of these issues, a subsequent study examined LepR-null mice where LepR was re-expressed selectively in kisspeptin cells. These mice showed no improvement to the infertile phenotype of LepR-null mice (Cravo et al. 2013), indicating that leptin signaling in kisspeptin neurons is not sufficient for fertility in mice.

Although it remains to be disproven as to whether leptin can act directly on kisspeptin neurons, indirect actions remain a likely possibility (Fig. 2). Indeed, in both studies refuting the direct role of leptin on kisspeptin neurons, a neuronal population expressing LepRb located in the ventral premammillary nucleus (PMV) was implicated (Donato et al. 2011, Louis et al. 2011). Notably, lesions of the PMV prevent the restoration of fertility following leptin treatment in $o b / o b$ mice and 're-expression' of LepRb in the PMV of female LepR-null mice is sufficient to induce sexual maturation (Donato et al. 2011). Moreover, PMV neurons appear to make close contacts with kisspeptin and GNRH neurons (Donato et al. 2011, Louis et al. 2011) and a yet to be characterized population of LepRb neurons is also present in close vicinity of Kiss1 neurons in both ARC and AVPV (Louis et al. 2011). So coordinated interplay between the PMV-kisspeptin-GNRH systems is likely. Overall, it can be concluded that PMV is a key site for leptin's permissive action at the onset of puberty and supports the hypothesis that leptin's role in controlling metabolism (via the ARC) and reproduction is anatomically dissociated (Coppari et al. 2005).

In spite of wealth of evidence demonstrating the effect of leptin on promoting fertility, and the involvement of kisspeptin neurons in mediating this effect (direct or indirect), the contribution of additional modulators of metabolism should not be ignored (see below). 
Data also suggest that leptin may not be the sole critical metabolic factor predicating the restoration of fertility in models of negative energy balance. In sheep, the restoration of ad libitum feeding in food-restricted ewes rescues pulsatile LH secretion but does so prior to any change in circulating leptin concentrations (Szymanski et al. 2007). Similarly, restoration of leptin to normal basal levels in caloric restricted female rats does not restore Kiss 1 mRNA or plasma LH levels (True et al. 2011). Although it could be argued in the latter that a required threshold of leptin was not reached because higher 'pharmacological' levels of leptin replacement in this study did maintain $\mathrm{LH}$ at control values (True et al. 2011). Nevertheless, alternative regulators of metabolism are very likely involved in kisspeptin regulation and should be explored.

\section{Insulin}

Insulin, the product of the pancreatic $\beta$ cells, is vital for the control of carbohydrate and fat metabolism and also plays a role in the hypothalamus to regulate energy balance (Schwartz et al. 1992). Moreover, central insulin signaling promotes fertility (Bruning et al. 2000) and, like leptin, appears to regulate GNRH neurons through an interneuronal mechanism (Divall et al. 2010). In foodrestricted ewes, the rescue of pulsatile $\mathrm{LH}$ secretion via restoration of ad libitum feeding (which occurs prior to any change in circulating leptin, see above) is preceded by an increase in circulating insulin concentrations (Szymanski et al. 2007), leading to the hypothesis that $\mathrm{LH}$ pulses are reinitiated by changes in availability of metabolic fuels and insulin.

Further, mice that are lacking insulin receptors selectively in kisspeptin neurons $\left(I R^{K i s s}\right.$ mice) experience a delay in puberty (Qiu et al. 2013). Specifically, female $I R^{\text {Kiss }}$ mice had delayed vaginal opening and first estrous, while males had reduced testis mass at postnatal day 31. These data indicate that kisspeptin neurons are likely mediators for the effects of insulin on reproduction. However, this phenotype appears to be limited to puberty onset because measures of adult fertility in these mice (levels of LH, FSH, sex steroids, as well as fertility) appeared unperturbed (Qiu et al. 2013). Consistent with the latter, insulin treatment does not appear to restore Kiss 1 mRNA expression in the whole hypothalamus of diabetics rats (Castellano et al. 2006). Thus, the role of kisspeptin neurons in mediating the effect of insulin on the reproductive axis still requires further clarification.

\section{Ghrelin}

Ghrelin is a stomach hormone commonly associated with the neural control of appetite and metabolism (Andrews 2011, Briggs \& Andrews 2011). However, unlike leptin or insulin, ghrelin operates as an orexigenic factor. Ghrelin also affects the reproductive system. For example, central ghrelin injection to OVX rats, or OVX rats treated with $\mathrm{E}_{2}$, suppressed $\mathrm{LH}$ concentration and pulse frequency (Furuta et al. 2001, Ogata et al. 2009). Similar inhibitory effects on $\mathrm{LH}$ secretion were observed throughout the estrus cycle (Fernandez-Fernandez et al. 2005). Here, ghrelin significantly inhibits GNRH release from hypothalamic explants and ghrelin suppressed GNRH-induced $\mathrm{LH}$ release in vitro (FernandezFernandez et al. 2005). The central inhibitory effects of ghrelin on LH secretion also occurs in sheep (lqbal et al. 2006). Thus, it appears that conditions of negative energy balance increase plasma ghrelin concentrations and in turn suppress the reproductive axis.

The mechanisms through which central ghrelin inhibits the reproductive system remain unresolved, although kisspeptin neurons in the hypothalamus may be a primary target. Previous studies highlight that ghrelin could inhibit LH secretion by directly suppressing the effects of kisspeptin on the reproductive axis. Ghrelin significantly reduced the duration of the $\mathrm{LH}$ secretory response to kisspeptin-10 (Martini et al. 2006). Moreover, during fasting, exogenous ghrelin treatment, or the combination of both, expression of Kiss 1 mRNA in the AVPV is reduced (Forbes et al. 2009), without affecting Kiss1 mRNA in the ARC, indicating that ghrelin may target these kisspeptin neurons to suppress LH secretion.

Ghrelin acts on the growth hormone secretagogue receptor (GHSR) in the brain to elicit changes in physiological functions. Although ghrelin suppresses LH secretion and regulates Kiss 1 mRNA, there is no clear neuroanatomical evidence linking GHSR neural circuits to reproductive neural circuits. We first examined direct coexpression of the GHSR and GNRH or kisspeptin neurons using a GHSR-eGFP reporter mouse line, which is currently the best model available to visualize GHSR expressing neurons. We showed for the first time that neither GNRH nor kisspeptin neurons in the AVPV express GHSR-eGFP, so any effect of ghrelin on these kisspeptin neurons must be indirect (Smith et al. 2013; Fig. 2). Importantly, we realize that these findings are reliant on the validity of the GHSReGFP model. In our study, we observed that only half of the GHSR-eGFP cells in the AVPV coexpressed Ghsr mRNA (as determined by in situ hybridization) and we remain cautious with the GHSR-eGFP mouse model and the interpretation of our data. Moreover, far fewer eGFP cells were localized to the ARC than expected. Given this, we can make no claim to the degree of GHSR-eGFP coexpression in kisspeptin neurons of the ARC. It remains likely that ARC kisspeptin neurons could coexpress GHSR and receive direct ghrelin input (Fig. 2) because expression of mRNA for both genes is prominent in this area (Gottsch et al. 2004, Zigman et al. 2006). 


\section{Hypothalamic regulators of kisspeptin}

If leptin, insulin, or ghrelin do not directly act on kisspeptin neurons, what are the possible indirect mechanisms? A realistic possibility may be the neuronal systems within the ARC responsible for integrating these peripheral metabolic signals and relaying effects on food intake and energy expenditure to higher brain centers. These neurons, termed 'first-order neurons' consist of neuropeptide $\mathrm{Y}$ (NPY)/agouti-related peptide (AgRP) neurons and pro-opiomelanocortin (POMC)/cocaine and amphetamine-regulated transcript (CART) neurons (Barsh \& Schwartz 2002). The majority of NPY/AgRP and POMC/CART neurons in the ARC contain LepRb, insulin receptor, and GHSR (Willesen et al. 1999, Barsh \& Schwartz 2002, Perello et al. 2012). Whether they are actively involved in the metabolic control of kisspeptin neurons is yet to shown.

\section{NPY/AgRP neurons}

A recent study suggests that NPY/AgRP neurons are involved in an important link between reproduction and metabolism ( $\mathrm{Wu}$ et al. 2012). These neurons are orexigenic and critical to initiate food intake (Aponte et al. 2011, Atasoy et al. 2012) and genetic ablation of AgRP neurons in adulthood results in starvation (Luquet et al. 2005). In order to examine the mechanisms underpinning hyperphagia in genetically obese and infertile ob/ob mice, Wu et al. (2012) discovered that ablating NPY/AgRP neurons in these mice caused a prolonged period of reduced food intake and remarkably restored fertility in both males and females. Consistent with this is the inhibitory effect of NPY on GNRH/LH secretion (Barker-Gibb et al. 1995, Xu et al. 2009). Interestingly, NPY may inhibit or stimulate LH secretion according to the steroid milieu in rats, inhibiting in OVX models, but stimulating in intact (Kalra \& Crowley 1984). In sheep, NPY only appears to have an inhibitory role on gonadotropin release (Barker-Gibb et al. 1995).

Despite the association, the effect of NPY on kisspeptin neurons is far from clear. In sheep, kisspeptin neurons receive neuroanatomically defined inputs from NPY/AgRP neurons (Backholer et al. 2010). However, in NPY KO mice, the expression of Kiss 1 mRNA appears to be reduced to levels similar to that during a fasted state (Luque et al. 2007). This is somewhat counterintuitive given that fasting, which reduces kisspeptin expression, stimulates the hypothalamic expression of NPY (Hahn et al. 1998). Leptin also appears to suppress NPY expression (Ahima 2000) but increases the expression of Kiss1 (Smith et al. 2006a). Nevertheless, the stimulatory role of NPY on Kiss 1 has also been shown in a hypothalamic cell line in vitro (Luque et al. 2007). Thus, the relationship between NPY and kisspeptin appears highly complex and one wonders what specific role AgRP may be playing (Fig. 3), particularly in regard

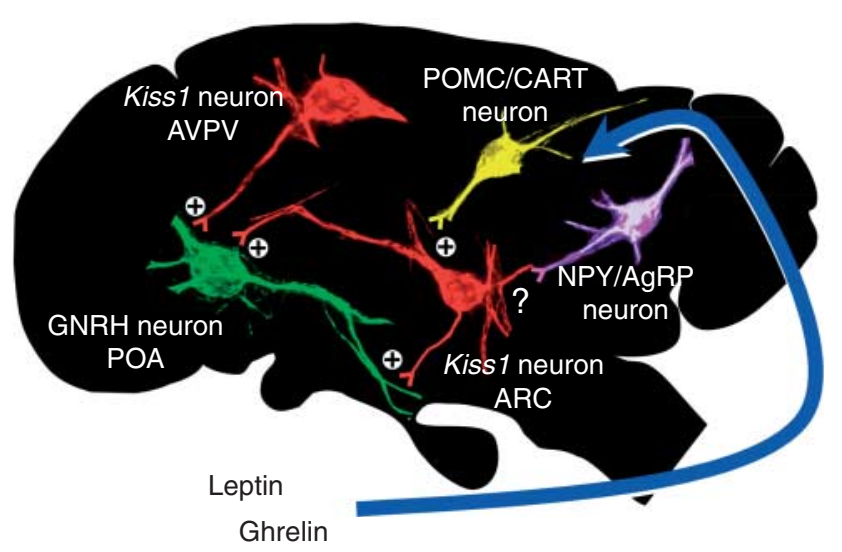

Figure 3 The potential involvement of NPY/AgRP and POMC/CART neurons in Kiss 1 neuron regulation. Regulators of metabolic function (leptin and ghrelin) regulate NPY/AgRP and POMC/CART neurons, which are neuroanatomicaly and functionally connected to Kiss 1 neurons. At this stage, NPY/AgRP regulation of Kiss 1 neurons is unclear (?). On the other hand, products of POMC/CART neurons appear to stimulate $(+)$ Kiss1 neurons.

to data obtained from NPY KO mice. Specific actions of AgRP on kisspeptin neurons are yet to be shown.

\section{POMC/CART neurons}

Juxtaposed to the NPY/AgRP neurons in the ARC are the POMC/CART neurons. These represent the major anorexigenic pathway in the control of food intake and energy expenditure (Barsh \& Schwartz 2002). Like their counterparts, POMC/CART neurons also send projections to kisspeptin neurons in sheep (Backholer et al. 2010) and mice (Cravo et al. 2011, True et al. 2013). In mice, subsets of kisspeptin neurons also express melanocortin receptor type 4 (Cravo et al. 2011) and melanocortin (one of the neuropeptides produced from these neurons) agonist (MTII) stimulates $\mathrm{LH}$ release in luteal phase ewes and increases Kiss 1 mRNA expression in the POA (Backholer et al. 2009). Of note, Kiss1 mRNA in the ARC was reduced in response to MTII (Backholer et al. 2009). The latter, while counterintuitive, could be explained due to a downstream effect of the possible reinstatement of $E_{2}$ levels following treatment as the experiment was performed in ovary intact seasonally anestrous ewes.

Very recent data have demonstrated that CART may also play a specific role in the regulation of kisspeptin. Using electrophysiological recordings from Kiss1-GFP mice, CART has been shown to postsynaptically depolarize kisspeptin neurons in the ARC (True et al. 2013). Thus, the stimulatory role of positive energy balance mediators on kisspeptin and fertility may also involve this neuropeptide (Fig. 3). Importantly, the authors here noted that CART could also directly activate GNRH neurons, using GNRH-GFP rats (True et al. 2013). This relationship was previously noted in mice for 
both products of POMC/CART neurons but also with NPY, showing Y1 receptor-mediated suppression of GNRH neuron activity (Roa \& Herbison 2012). Thus, although evidence shows that first-order neuron regulation of kisspeptin is possible, these neurons can also provide a kisspeptin-independent route through which neuropeptide metabolic cues can directly regulate $\mathrm{GNRH}$ and fertility.

\section{Kisspeptin-mediated control of energy balance?}

While most of the focus of current research has been on the role of kisspeptin in relaying metabolic signals to the reproductive axis, little attention has been paid to the potential role for kisspeptin as a regulator of energy balance. It is not uncommon for neuroendocrine systems to possess reciprocal control of feeding behavior and reproduction (Small et al. 2002, Tena-Sempere 2007). Moreover, Kiss $1 r$ is expressed in a number of brain areas that do not contain GNRH (Herbison et al. 2010), as well as in several peripheral tissues (Kotani et al. 2001), including metabolic tissues such as pancreas and adipose tissue (Brown et al. 2008). Thus, it is possible that kisspeptin signaling may have additional roles beyond the control of reproduction. However, this has not yet been shown.

Kiss 1 and Kiss1r KO mice do not appear to have any difference in body weights compared with WT littermates (Lapatto et al. 2007), and initial studies on rats found no effects of central kisspeptin administration on food intake, bodyweight, or the hypothalamic expression of NPY, AgRP, POMC, or CART (Castellano et al. 2005). Similarly, kisspeptin treatment had no effect on food intake in sheep (Clarke et al. 2012), so any contribution of kisspeptin in the control of energy balance seemed unlikely. However, it its worth noting here that DBA/2J mice, which are much more susceptible to high-fat DIO and infertility, have substantially less Kiss1 mRNA in the AVPV and ARC (Quennell et al. 2011). Moreover, body weights in Kiss 1 and Kiss $1 r$ KO mice have only been reported before full maturity, and the examination of the entire metabolic characteristics of these mice has not yet been performed.

In opposition to this precedent, kisspeptin neurons send afferents to first-order NPY/AgRP and POMC/CART neurons (Backholer et al. 2010). These neurons may possess Kiss1r because it is expressed in cells within the ARC (Lee et al. 1999), which are not kisspeptin neurons (Smith et al. 2011). Moreover, electrophysiological recordings in mice show that kisspeptin can directly excite POMC/CART neurons and indirectly inhibit NPY/ AgRP neurons, via a mechanism based on enhancing GABA-mediated inhibitory synaptic tone (Fu \& van den Pol 2010). The net effect of such kisspeptin regulation would be to decrease food intake and increase metabolism. Consistent with this, central administration of kisspeptin was recently shown to increase meal intervals, reducing nocturnal food intake in mice (Stengel et al. 2011). Alternatively, central administration of kisspeptin in sheep was reported to inhibit POMC and increase NPY mRNA expression in the ARC (Backholer et al. 2010). Although counterintuitive, this effect may relate to possible antagonistic properties of the continuous kisspeptin infusion (which lasted for $20 \mathrm{~h}$ ). Such treatment has been previously shown to desensitize Kiss $1 r$-induced GNRH release (Seminara et al. 2006) and reduced Kiss1r mRNA expression on GNRH neurons (Li et al. 2012). Nevertheless, similar data (kisspeptin treatment stimulating NPY secretion) are also apparent using a cell line (Kim et al. 2010). So the precise role of kisspeptin in regulating the POMC/CART and/or NPY/ AgRP systems is clouded and awaits closer inspection.

In another layer of complexity, recent data have shown that saporin ablation of kisspeptin neurons in the ARC prevents the known effects of OVX and $E_{2}$ replacement on bodyweight in rats (Mittelman-Smith et al. 2012a). Apart from their role in reproduction, $E_{2}$ is known to act in the brain via $E R \alpha$ to alter body composition by decreasing food intake and increasing energy expenditure (Xu et al. 2011). Thus, it appears that ARC kisspeptin neurons are required for the orexigenic effect of OVX. In addition, a follow-up study with kisspeptin neurons ablation demonstrated that $E_{2}$ and kisspeptin appear to have apposing actions on skin temperature (MittelmanSmith et al. 2012b), perhaps predicating a role for kisspeptin in thermogenesis and energy expenditure. While encouraging, these data are at odds with the proposed role for kisspeptin, which (like $E_{2}$ ) is to decrease food intake and increase energy expenditure. Of significance here is that the ablation of kisspeptin neurons would also eliminate NKB and dynorphin signaling (as these are coexpressed in these neurons (Goodman et al. 2007)). The roles that these other neuropeptides have on energy balance and their potential role in the above phenomenon need to be confirmed.

Finally, a role for kisspeptin on energy balance may occur outside the hypothalamus. As stated above, Kiss1r is expressed in the pancreas (Kotani et al. 2001) and adipose tissue (Brown et al. 2008). In the former, kisspeptin has been shown to play a physiological role. Kisspeptin appears to be capable of stimulating insulin release in vitro in mice and in vivo in rats (Bowe et al. 2009). These data, however, have been challenged by similar studies displaying an inhibitory effect of kisspeptin on insulin secretion in isolated mouse islets (Vikman \& Ahren 2009). Clearly, more work is necessary to decipher the role that kisspeptin signaling is playing here and in other potential peripheral tissues.

\section{Conclusion}

Kisspeptin is a vital component for the neuroendocrine regulation of GNRH secretion. As such, it has been a 


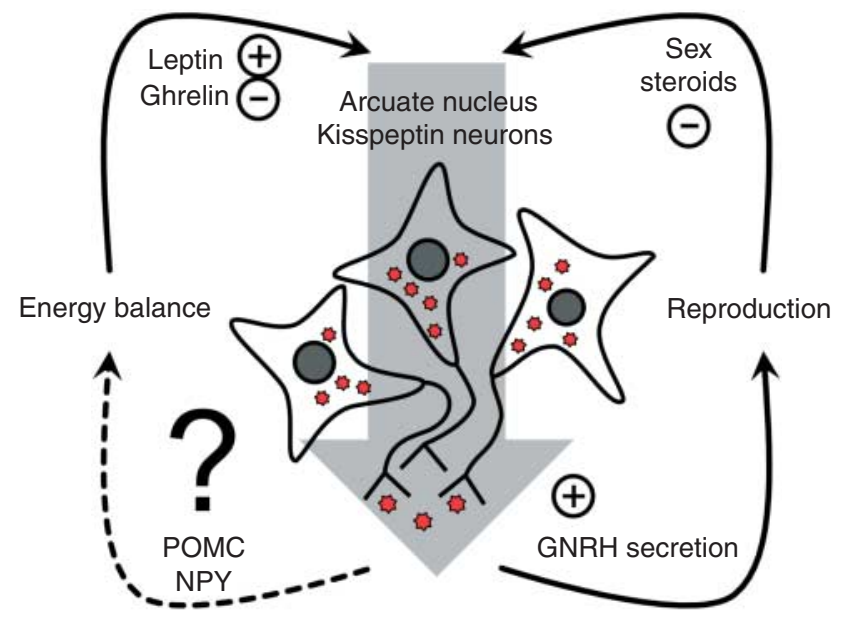

Figure 4 The relationship between energy balance and reproduction. We propose that kisspeptin neurons in the arcuate nucleus are central to this integrated regulatory loop, forming a link between energy balance and reproduction. Concerning reproduction, kisspeptin neurons stimulate $(+)$ GNRH secretion and ultimately gonadal steroid production. These hormones then feed back $(-)$ and regulate kisspeptin output. Concerning energy balance, metabolic signals such as leptin and ghrelin modulate fertility via kisspeptin regulation. Kisspeptin may potentially regulate energy balance circuits (stimulating POMC and inhibiting NPY) in a feedback mechanism similar to that of reproduction. But whether kisspeptin has clear effects on energy balance is yet to be shown (?).

focus for the central pathway responsible for conveying key homeostatic information to GNRH neurons (Fig. 4). Multiple studies have implicated kisspeptin signaling as a conduit for the well-established link between energy balance and reproductive function. While the precise metabolic pathway is yet to be fully understood, the peripheral signals leptin, insulin, and ghrelin are likely to play a role, as are POMC/CART and NPY/AgRP neurons in the ARC. Finally, a direct role for kisspeptin in mediating energy balance is now gathering momentum. Future studies are required to confirm this possibility and determine its physiological relevance.

\section{Declaration of interest}

The authors declare that there is no conflict of interest that could be perceived as prejudicing the impartiality of the review reported.

\section{Funding}

J T Smith is supported by an Australian Research Council Future Fellowship (FT0990986) and project grants (DP120100521 and DP140102495).

\section{References}

Ahima RS 2000 Leptin and the neuroendocrinology of fasting. Frontiers of Hormone Research 26 42-56. (doi:10.1159/000061014)
Andrews ZB 2011 Central mechanisms involved in the orexigenic actions of ghrelin. Peptides 32 2248-2255. (doi:10.1016/j.peptides. 2011.05.014)

d'Anglemont de Tassigny X, Fagg LA, Carlton MB \& Colledge WH 2008 Kisspeptin can stimulate gonadotropin-releasing hormone $(\mathrm{GnRH})$ release by a direct action at $\mathrm{GnRH}$ nerve terminals. Endocrinology 149 3926-3932. (doi:10.1210/en.2007-1487)

Aponte Y, Atasoy D \& Sternson SM 2011 AGRP neurons are sufficient to orchestrate feeding behavior rapidly and without training. Nature Neuroscience 14 351-355. (doi:10.1038/nn.2739)

Atasoy D, Betley JN, Su HH \& Sternson SM 2012 Deconstruction of a neural circuit for hunger. Nature 488 172-177. (doi:10.1038/ nature11270)

Backholer K, Smith JT \& Clarke IJ 2009 Melanocortins may stimulate reproduction by activating orexin neurons in the dorsomedial hypothalamus and kisspeptin neurons in the preoptic area of the ewe. Endocrinology 150 5488-5497. (doi:10.1210/en.2009-0604)

Backholer K, Smith JT, Rao A, Pereira A, Iqbal J, Ogawa S, Li Q \& Clarke IJ 2010 Kisspeptin cells in the ewe brain respond to leptin and communicate with neuropeptide $\mathrm{Y}$ and proopiomelanocortin cells. Endocrinology 151 2233-2243. (doi:10.1210/en.2009-1190)

Barker-Gibb ML, Scott CJ, Boublik JH \& Clarke IJ 1995 The role of neuropeptide $\mathrm{Y}$ (NPY) in the control of LH secretion in the ewe with respect to season, NPY receptor subtype and the site of action in the hypothalamus. Journal of Endocrinology 147 565-579. (doi:10.1677/ joe.0.1470565)

Barsh GS \& Schwartz MW 2002 Genetic approaches to studying energy balance: perception and integration. Nature Reviews. Genetics 3 589-600.

Bowe JE, King AJ, Kinsey-Jones JS, Foot VL, Li XF, O'Byrne KT, Persaud SJ \& Jones PM 2009 Kisspeptin stimulation of insulin secretion: mechanisms of action in mouse islets and rats. Diabetologia 52 855-862. (doi:10. 1007/s00125-009-1283-1)

Briggs DI \& Andrews ZB 2011 Metabolic status regulates ghrelin function on energy homeostasis. Neuroendocrinology 93 48-57. (doi:10.1159/ 000322589)

Brown RE, Imran SA, Ur E \& Wilkinson M 2008 KiSS-1 mRNA in adipose tissue is regulated by sex hormones and food intake. Molecular and Cellular Endocrinology 281 64-72. (doi:10.1016/j.mce.2007.10.011)

Bruning JC, Gautam D, Burks DJ, Gillette J, Schubert M, Orban PC, Klein R, Krone W, Muller-Wieland D \& Kahn CR 2000 Role of brain insulin receptor in control of body weight and reproduction. Science $\mathbf{2 8 9}$ 2122-2125. (doi:10.1126/science.289.5487.2122)

Castellano JM, Navarro VM, Fernandez-Fernandez R, Nogueiras R, Tovar S, Roa J, Vazquez MJ, Vigo E, Casanueva FF, Aguilar E et al. 2005 Changes in hypothalamic KiSS-1 system and restoration of pubertal activation of the reproductive axis by kisspeptin in undernutrition. Endocrinology 146 3917-3925. (doi:10.1210/en.2005-0337)

Castellano JM, Navarro VM, Fernandez-Fernandez R, Roa J, Vigo E, Pineda R, Dieguez C, Aguilar E, Pinilla L \& Tena-Sempere M 2006 Expression of hypothalamic KiSS-1 system and rescue of defective gonadotropic responses by kisspeptin in streptozotocin-induced diabetic male rats. Diabetes 55 2602-2610. (doi:10.2337/db05-1584)

Chehab FF 2000 Leptin as a regulator of adipose mass and reproduction. Trends in Pharmacological Sciences 21 309-314. (doi:10.1016/S01656147(00)01514-5)

Cheung CC, Thornton JE, Kuijper JL, Weigle DS, Clifton DK \& Steiner RA 1997 Leptin is a metabolic gate for the onset of puberty in the female rat. Endocrinology 138 855-858. (doi:10.1210/en.138.2.855)

Clarke IJ, Smith JT, Henry BA, Oldfield BJ, Stefanidis A, Millar RP, Sari IP, Chng K, Fabre-Nys C, Caraty A et al. 2012 Gonadotropin-inhibitory hormone is a hypothalamic peptide that provides a molecular switch between reproduction and feeding. Neuroendocrinology 95 305-316. (doi:10.1159/000332822)

Clarkson J \& Herbison AE 2006 Postnatal development of kisspeptin neurons in mouse hypothalamus; sexual dimorphism and projections to gonadotropin-releasing hormone neurons. Endocrinology 147 5817-5825. (doi:10.1210/en.2006-0787)

Compagnucci C, Compagnucci GE, Lomniczi A, Mohn C, Vacas I, Cebral E, Elverdin JC, Friedman S, Rettori V \& Boyer PM 2002 Effect of nutritional stress on the hypothalamo-pituitary-gonadal axis in the growing male rat. Neuroimmunomodulation 10 153-162. (doi:10.1159/000067177) 
Coppari R, Ichinose M, Lee CE, Pullen AE, Kenny CD, McGovern RA, Tang V, Liu SM, Ludwig T, Chua SC Jr et al. 2005 The hypothalamic arcuate nucleus: a key site for mediating leptin's effects on glucose homeostasis and locomotor activity. Cell Metabolism 1 63-72. (doi:10.1016/j.cmet.2004.12.004)

Cravo RM, Margatho LO, Osborne-Lawrence S, Donato J, Atkin S, Bookout AL, Rovinsky S, Frazao R, Lee CE, Gautron L et al. 2011 Characterization of Kiss1 neurons using transgenic mouse models. Neuroscience 173 37-56. (doi:10.1016/j.neuroscience.2010.11.022)

Cravo RM, Frazao R, Perello M, Osborne-Lawrence S, Williams KW, Zigman JM, Vianna C \& Elias CF 2013 Leptin signaling in kiss1 neurons arises after pubertal development. PLOS ONE 8 e58698. (doi:10.1371/ journal.pone.0058698)

Divall SA, Williams TR, Carver SE, Koch L, Bruning JC, Kahn CR, Wondisford F, Radovick S \& Wolfe A 2010 Divergent roles of growth factors in the $\mathrm{GnRH}$ regulation of puberty in mice. Journal of Clinical Investigation 120 2900-2909. (doi:10.1172/JCl41069)

Donato J Jr, Cravo RM, Frazao R, Gautron L, Scott MM, Lachey J, Castro IA, Margatho LO, Lee S, Lee C et al. 2011 Leptin's effect on puberty in mice is relayed by the ventral premammillary nucleus and does not require signaling in Kiss1 neurons. Journal of Clinical Investigation 121 355-368. (doi:10.1172/JCl45106)

Dungan HM, Gottsch ML, Zeng H, Gragerov A, Bergmann JE, Vassilatis DK, Clifton DK \& Steiner RA 2007 The role of kisspeptinGPR54 signaling in the tonic regulation and surge release of gonadotropin-releasing hormone/luteinizing hormone. Journal of Neuroscience 27 12088-12095. (doi:10.1523/JNEUROSCI.2748-07.2007)

Estrada KM, Clay CM, Pompolo S, Smith JT \& Clarke IJ 2006 Elevated KiSS-1 expression in the arcuate nucleus prior to the cyclic preovulatory gonadotrophin-releasing hormone/lutenising hormone surge in the ewe suggests a stimulatory role for kisspeptin in oestrogen-positive feedback. Journal of Neuroendocrinology 18 806-809. (doi:10.1111/j.1365-2826. 2006.01485.x)

Evans JJ \& Anderson GM 2012 Balancing ovulation and anovulation: integration of the reproductive and energy balance axes by neuropeptides. Human Reproduction Update 18 313-332. (doi:10.1093/ humupd/dms004)

Fernandez-Fernandez $R$, Tena-Sempere $M$, Navarro VM, Barreiro ML, Castellano JM, Aguilar E \& Pinilla L 2005 Effects of ghrelin upon gonadotropin-releasing hormone and gonadotropin secretion in adult female rats: in vivo and in vitro studies. Neuroendocrinology $\mathbf{8 2}$ 245-255. (doi:10.1159/000092753)

Forbes S, Li XF, Kinsey-Jones J \& O'Byrne K 2009 Effects of ghrelin on Kisspeptin mRNA expression in the hypothalamic medial preoptic area and pulsatile luteinising hormone secretion in the female rat. Neuroscience Letters 460 143-147. (doi:10.1016/j.neulet.2009.05.060)

Fu LY \& van den Pol AN 2010 Kisspeptin directly excites anorexigenic proopiomelanocortin neurons but inhibits orexigenic neuropeptide $Y$ cells by an indirect synaptic mechanism. Journal of Neuroscience $\mathbf{3 0}$ 10205-10219. (doi:10.1523/JNEUROSCI.2098-10.2010)

Furuta M, Funabashi T \& Kimura F 2001 Intracerebroventricular administration of ghrelin rapidly suppresses pulsatile luteinizing hormone secretion in ovariectomized rats. Biochemical and Biophysical Research Communications 288 780-785. (doi:10.1006/bbrc. 2001.5854)

Gaytan F, Gaytan M, Castellano JM, Romero M, Roa J, Aparicio B, Garrido N, Sanchez-Criado JE, Millar RP, Pellicer A et al. 2009 KiSS-1 in the mammalian ovary: distribution of kisspeptin in human and marmoset and alterations in KiSS-1 mRNA levels in a rat model of ovulatory dysfunction. American Journal of Physiology. Endocrinology and Metabolism 296 E520-E531. (doi:10.1152/ajpendo.90895.2008)

Ghanayem BI, Bai R, Kissling GE, Travlos G \& Hoffler U 2010 Diet-induced obesity in male mice is associated with reduced fertility and potentiation of acrylamide-induced reproductive toxicity. Biology of Reproduction $\mathbf{8 2}$ 96-104. (doi:10.1095/biolreprod.109.078915)

Goodman RL, Lehman MN, Smith JT, Coolen LM, de Oliveira CV, Jafarzadehshirazi MR, Pereira A, Iqbal J, Caraty A, Ciofi P et al. 2007 Kisspeptin neurons in the arcuate nucleus of the ewe express both dynorphin A and neurokinin B. Endocrinology 148 5752-5760. (doi:10.1210/en.2007-0961)

Gottsch ML, Cunningham MJ, Smith JT, Popa SM, Acohido BV, Crowley WF, Seminara S, Clifton DK \& Steiner RA 2004 A role for kisspeptins in the regulation of gonadotropin secretion in the mouse. Endocrinology 145 4073-4077. (doi:10.1210/en.2004-0431)
Gottsch ML, Clifton DK \& Steiner RA 2009 From KISS1 to kisspeptins: an historical perspective and suggested nomenclature. Peptides 30 4-9. (doi:10.1016/j.peptides.2008.06.016)

Gottsch ML, Popa SM, Lawhorn JK, Qiu J, Tonsfeldt KJ, Bosch MA, Kelly MJ, Ronnekleiv OK, Sanz E, McKnight GS et al. 2011 Molecular properties of Kiss1 neurons in the arcuate nucleus of the mouse. Endocrinology 152 4298-4309. (doi:10.1210/en.2011-1521)

Hahn TM, Breininger JF, Baskin DG \& Schwartz MW 1998 Coexpression of Agrp and NPY in fasting-activated hypothalamic neurons. Nature Neuroscience 1 271-272. (doi:10.1038/1082)

Halaas JL, Gajiwala KS, Maffei M, Cohen SL, Chait BT, Rabinowitz D, Lallone RL, Burley SK \& Friedman JM 1995 Weight-reducing effects of the plasma protein encoded by the obese gene. Science 269 543-546. (doi:10.1126/science.7624777)

Han SK, Gottsch ML, Lee KJ, Popa SM, Smith JT, Jakawich SK, Clifton DK, Steiner RA \& Herbison AE 2005 Activation of gonadotropin-releasing hormone neurons by kisspeptin as a neuroendocrine switch for the onset of puberty. Journal of Neuroscience 25 11349-11356. (doi:10.1523/ JNEUROSCI.3328-05.2005)

Herbison AE 2008 Estrogen positive feedback to gonadotropin-releasing hormone $(\mathrm{GnRH})$ neurons in the rodent: the case for the rostral periventricular area of the third ventricle (RP3V). Brain Research Reviews 57 277-287. (doi:10.1016/j.brainresrev.2007.05.006)

Herbison AE, de Tassigny X, Doran J \& Colledge WH 2010 Distribution and postnatal development of Gpr54 gene expression in mouse brain and gonadotropin-releasing hormone neurons. Endocrinology 151 312-321. (doi:10.1210/en.2009-0552)

Hoffman GE, Le WW, Franceschini I, Caraty A \& Advis JP 2011 Expression of fos and in vivo median eminence release of LHRH identifies an active role for preoptic area kisspeptin neurons in synchronized surges of $\mathrm{LH}$ and LHRH in the ewe. Endocrinology 152 214-222. (doi:10.1210/ en.2010-0066)

Iqbal J, Kurose Y, Canny B \& Clarke IJ 2006 Effects of central infusion of ghrelin on food intake and plasma levels of growth hormone, luteinizing hormone, prolactin, and cortisol secretion in sheep. Endocrinology 147 510-519. (doi:10.1210/en.2005-1048)

Irwig MS, Fraley GS, Smith JT, Acohido BV, Popa SM, Cunningham MJ, Gottsch ML, Clifton DK \& Steiner RA 2004 Kisspeptin activation of gonadotropin releasing hormone neurons and regulation of KiSS-1 mRNA in the male rat. Neuroendocrinology 80 264-272. (doi:10.1159/ 000083140)

Kalamatianos T, Grimshaw SE, Poorun R, Hahn JD \& Coen CW 2008 Fasting reduces KiSS-1 expression in the anteroventral periventricular nucleus (AVPV): effects of fasting on the expression of KiSS-1 and neuropeptide $\mathrm{Y}$ in the AVPV or arcuate nucleus of female rats. Journal of Neuroendocrinology 20 1089-1097. (doi:10.1111/j.1365-2826.2008. 01757.x)

Kalra SP \& Crowley WR 1984 Norepinephrine-like effects of neuropeptide $\mathrm{Y}$ on LH release in the rat. Life Sciences 35 1173-1176. (doi:10.1016/ 0024-3205(84)90187-5)

Kauffman AS, Park JH, McPhie-Lalmansingh AA, Gottsch ML, Bodo C, Hohmann JG, Pavlova MN, Rohde AD, Clifton DK, Steiner RA et al. 2007 The kisspeptin receptor GPR54 is required for sexual differentiation of the brain and behavior. Journal of Neuroscience 27 8826-8835. (doi:10.1523/JNEUROSCI.2099-07.2007)

Kim GL, Dhillon SS \& Belsham DD 2010 Kisspeptin directly regulates neuropeptide $Y$ synthesis and secretion via the ERK1/2 and p38 mitogenactivated protein kinase signaling pathways in NPY-secreting hypothalamic neurons. Endocrinology 151 5038-5047. (doi:10.1210/ en.2010-0521)

Kinoshita M, Tsukamura H, Adachi S, Matsui H, Uenoyama Y, Iwata K, Yamada S, Inoue K, Ohtaki T, Matsumoto H et al. 2005 Involvement of central metastin in the regulation of preovulatory luteinizing hormone surge and estrous cyclicity in female rats. Endocrinology 146 4431-4436. (doi:10.1210/en.2005-0195)

Kotani $M$, Detheux $M$, Vandenbogaerde A, Communi D, Vanderwinden JM, Le Poul E, Brezillon S, Tyldesley R, SuarezHuerta N, Vandeput $\mathbf{F}$ et al. 2001 The metastasis suppressor gene KiSS-1 encodes kisspeptins, the natural ligands of the orphan G proteincoupled receptor GPR54. Journal of Biological Chemistry 276 34631-34636. (doi:10.1074/jbc.M104847200) 
Lapatto R, Pallais JC, Zhang D, Chan YM, Mahan A, Cerrato F, Le WW, Hoffman GE \& Seminara SB 2007 Kiss1 - / - mice exhibit more variable hypogonadism than Gpr54-/- mice. Endocrinology 148 4927-4936. (doi:10.1210/en.2007-0078)

Lee DK, Nguyen T, $\mathrm{O}^{\prime}$ Neill GP, Cheng R, Liu Y, Howard AD, Coulombe N, Tan CP, Tang-Nguyen AT, George SR et al. 1999 Discovery of a receptor related to the galanin receptors. FEBS Letters 446 103-107. (doi:10.1016/ S0014-5793(99)00009-5)

Li Q, Roa A, Clarke IJ \& Smith JT 2012 Seasonal variation in the gonadotropin-releasing hormone response to kisspeptin in sheep: possible kisspeptin regulation of the kisspeptin receptor. Neuroendocrinology 96 212-221. (doi:10.1159/000335998)

Louis GW, Greenwald-Yarnell M, Phillips R, Coolen LM, Lehman MN \& Myers MG Jr 2011 Molecular mapping of the neural pathways linking leptin to the neuroendocrine reproductive axis. Endocrinology 152 2302-2310. (doi:10.1210/en.2011-0096)

de Luca C, Kowalski TJ, Zhang Y, Elmquist JK, Lee C, Kilimann MW, Ludwig T, Liu SM \& Chua SC Jr 2005 Complete rescue of obesity, diabetes, and infertility in $d b / d b$ mice by neuron-specific LEPR-B transgenes. Journal of Clinical Investigation 115 3484-3493. (doi:10.1172/JCI24059)

Luque RM, Kineman RD \& Tena-Sempere M 2007 Regulation of hypothalamic expression of KiSS-1 and GPR54 genes by metabolic factors: analyses using mouse models and a cell line. Endocrinology 148 4601-4611. (doi:10.1210/en.2007-0500)

Luquet S, Perez FA, Hnasko TS \& Palmiter RD 2005 NPY/AgRP neurons are essential for feeding in adult mice but can be ablated in neonates. Science 310 683-685. (doi:10.1126/science.1115524)

Martini AC, Fernandez-Fernandez R, Tovar S, Navarro VM, Vigo E, Vazquez MJ, Davies JS, Thompson NM, Aguilar E, Pinilla L et al. 2006 Comparative analysis of the effects of ghrelin and unacylated ghrelin on luteinizing hormone secretion in male rats. Endocrinology 147 2374-2382. (doi:10.1210/en.2005-1422)

Matsui H, Takatsu Y, Kumano S, Matsumoto H \& Ohtaki T 2004 Peripheral administration of metastin induces marked gonadotropin release and ovulation in the rat. Biochemical and Biophysical Research Communications 320 383-388. (doi:10.1016/j.bbrc.2004.05.185)

Mayer C \& Boehm U 2011 Female reproductive maturation in the absence of kisspeptin/GPR54 signaling. Nature Neuroscience 14 704-710. (doi:10.1038/nn.2818)

Messager S, Chatzidaki EE, Ma D, Hendrick AG, Zahn D, Dixon J, Thresher RR, Malinge I, Lomet D, Carlton MB et al. 2005 Kisspeptin directly stimulates gonadotropin-releasing hormone release via G protein-coupled receptor 54. PNAS 102 1761-1766. (doi:10.1073/ pnas.0409330102)

Mittelman-Smith MA, Williams H, Krajewski-Hall SJ, Lai J, Ciofi P, McMullen NT \& Rance NE 2012a Arcuate kisspeptin/neurokinin $\mathrm{B} /$ dynorphin (KNDy) neurons mediate the estrogen suppression of gonadotropin secretion and body weight. Endocrinology 153 2800-2812. (doi:10.1210/en.2012-1045)

Mittelman-Smith MA, Williams H, Krajewski-Hall SJ, McMullen NT \& Rance NE 2012b Role for kisspeptin/neurokinin B/dynorphin (KNDy) neurons in cutaneous vasodilatation and the estrogen modulation of body temperature. PNAS 109 19846-19851. (doi:10.1073/pnas. 1211517109)

Ogata R, Matsuzaki T, Iwasa T, Kiyokawa M, Tanaka N, Kuwahara A, Yasui T \& Irahara M 2009 Hypothalamic ghrelin suppresses pulsatile secretion of luteinizing hormone via $\beta$-endorphin in ovariectomized rats. Neuroendocrinology 90 364-370. (doi:10.1159/000257421)

Ohtaki T, Shintani Y, Honda S, Matsumoto H, Hori A, Kanehashi K, Terao Y, Kumano S, Takatsu Y, Masuda Y et al. 2001 Metastasis suppressor gene KiSS-1 encodes peptide ligand of a G-protein-coupled receptor. Nature 411 613-617. (doi:10.1038/35079135)

Pasquali R, Patton L \& Gambineri A 2007 Obesity and infertility. Current Opinion in Endocrinology, Diabetes, and Obesity 14 482-487. (doi:10.1097/MED.0b013e3282f1d6cb)

Patterson M, Murphy KG, Thompson EL, Patel S, Ghatei MA \& Bloom SR 2006 Administration of kisspeptin-54 into discrete regions of the hypothalamus potently increases plasma luteinising hormone and testosterone in male adult rats. Journal of Neuroendocrinology $\mathbf{1 8}$ 349-354. (doi:10.1111/j.1365-2826.2006.01420.x)

Perello M, Scott MM, Sakata I, Lee CE, Chuang JC, Osborne-Lawrence S, Rovinsky SA, Elmquist JK \& Zigman JM 2012 Functional implications of limited leptin receptor and ghrelin receptor coexpression in the brain. Journal of Comparative Neurology $\mathbf{5 2 0}$ 281-294. (doi:10.1002/ cne.22690)

Pielecka-Fortuna J, Chu Z \& Moenter SM 2008 Kisspeptin acts directly and indirectly to increase gonadotropin-releasing hormone neuron activity and its effects are modulated by estradiol. Endocrinology 149 1979-1986. (doi:10.1210/en.2007-1365)

Popa SM, Moriyama RM, Caligioni CS, Yang JJ, Cho CM, Concepcion TL, Oakley AE, Lee IH, Sanz E, Amieux PS et al. 2013 Redundancy in Kiss 1 expression safeguards reproduction in the mouse. Endocrinology 154 2784-2794. (doi:10.1210/en.2013-1222)

Qiu J, Fang Y, Bosch MA, Ronnekleiv OK \& Kelly MJ 2011 Guinea pig kisspeptin neurons are depolarized by leptin via activation of TRPC channels. Endocrinology 152 1503-1514. (doi:10.1210/en. 2010-1285)

Qiu X, Dowling AR, Marino JS, Faulkner LD, Bryant B, Bruning JC, Elias CF \& Hill JW 2013 Delayed puberty but normal fertility in mice with selective deletion of insulin receptors from Kiss 1 cells. Endocrinology 154 1337-1348. (doi:10.1210/en.2012-2056)

Quennell JH, Mulligan AC, Tups A, Liu X, Phipps SJ, Kemp CJ, Herbison AE, Grattan DR \& Anderson GM 2009 Leptin indirectly regulates gonadotropin-releasing hormone neuronal function. Endocrinology 150 2805-2812. (doi:10.1210/en.2008-1693)

Quennell JH, Howell CS, Roa J, Augustine RA, Grattan DR \& Anderson GM 2011 Leptin deficiency and diet-induced obesity reduce hypothalamic kisspeptin expression in mice. Endocrinology 152 1541-1550. (doi:10.1210/en.2010-1100)

Roa J \& Herbison AE 2012 Direct regulation of GnRH neuron excitability by arcuate nucleus POMC and NPY neuron neuropeptides in female mice. Endocrinology 153 5587-5599. (doi:10.1210/en.2012-1470)

Roa J, Garcia-Galiano D, Varela L, Sanchez-Garrido MA, Pineda R, Castellano JM, Ruiz-Pino F, Romero M, Aguilar E, Lopez M et al. 2009 The mammalian target of rapamycin as novel central regulator of puberty onset via modulation of hypothalamic Kiss1 system. Endocrinology $\mathbf{1 5 0}$ 5016-5026. (doi:10.1210/en.2009-0096)

de Roux N, Genin E, Carel JC, Matsuda F, Chaussain JL \& Milgrom E 2003 Hypogonadotropic hypogonadism due to loss of function of the KiSS1-derived peptide receptor GPR54. PNAS 100 10972-10976. (doi:10.1073/pnas.1834399100)

Schwartz MW, Figlewicz DP, Baskin DG, Woods SC \& Porte D Jr 1992 Insulin in the brain: a hormonal regulator of energy balance. Endocrine Reviews 13 387-414.

Seminara SB, Messager S, Chatzidaki EE, Thresher RR, Acierno JS Jr, Shagoury JK, Bo-Abbas Y, Kuohung W, Schwinof KM, Hendrick AG et al. 2003 The GPR54 gene as a regulator of puberty. New England Journal of Medicine 349 1614-1627. (doi:10.1056/NEJMoa035322)

Seminara SB, Dipietro MJ, Ramaswamy S, Crowley WF Jr \& Plant TM 2006 Continuous human metastin 45-54 infusion desensitizes G proteincoupled receptor 54-induced gonadotropin-releasing hormone release monitored indirectly in the juvenile male Rhesus monkey (Macaca mulatta): a finding with therapeutic implications. Endocrinology 147 2122-2126. (doi:10.1210/en.2005-1550)

Shahab M, Mastronardi C, Seminara SB, Crowley WF, Ojeda SR \& Plant TM 2005 Increased hypothalamic GPR54 signaling: a potential mechanism for initiation of puberty in primates. PNAS 102 2129-2134. (doi:10.1073/pnas.0409822102)

Simerly RB 2002 Wired for reproduction: organization and development of sexually dimorphic circuits in the mammalian forebrain. Annual Review of Neuroscience 25 507-536. (doi:10.1146/annurev.neuro.25.112701. 142745)

Small CJ, Stanley SA \& Bloom SR 2002 Appetite control and reproduction: leptin and beyond. Seminars in Reproductive Medicine 20 389-398. (doi:10.1055/s-2002-36712)

Smith JT 2013 Sex steroid regulation of kisspeptin circuits. Advances in Experimental Medicine and Biology 784 275-295.

Smith JT, Cunningham MJ, Rissman EF, Clifton DK \& Steiner RA 2005a Regulation of Kiss1 gene expression in the brain of the female mouse. Endocrinology 146 3686-3692. (doi:10.1210/en.2005-0488)

Smith JT, Dungan HM, Stoll EA, Gottsch ML, Braun RE, Eacker SM, Clifton DK \& Steiner RA 2005b Differential regulation of KiSS-1 mRNA expression by sex steroids in the brain of the male mouse. Endocrinology 146 2976-2984. (doi:10.1210/en.2005-0323) 
Smith JT, Acohido BV, Clifton DK \& Steiner RA 2006a KiSS-1 neurones are direct targets for leptin in the ob/ob mouse. Journal of Neuroendocrinology 18 298-303. (doi:10.1111/j.1365-2826.2006.01417.x)

Smith JT, Popa SM, Clifton DK, Hoffman GE \& Steiner RA $2006 b$ Kiss1 neurons in the forebrain as central processors for generating the preovulatory luteinizing hormone surge. Journal of Neuroscience $\mathbf{2 6}$ 6687-6694. (doi:10.1523/JNEUROSCI.1618-06.2006)

Smith JT, Clay CM, Caraty A \& Clarke IJ 2007 KiSS-1 messenger ribonucleic acid expression in the hypothalamus of the ewe is regulated by sex steroids and season. Endocrinology 148 1150-1157. (doi:10.1210/en.2006-1435)

Smith JT, Coolen LM, Kriegsfeld LJ, Sari IP, Jaafarzadehshirazi MR, Maltby M, Bateman K, Goodman RL, Tilbrook AJ, Ubuka T et al. 2008 Variation in kisspeptin and RFamide-related peptide (RFRP) expression and terminal connections to gonadotropin-releasing hormone neurons in the brain: a novel medium for seasonal breeding in the sheep. Endocrinology 149 5770-5782. (doi:10.1210/en.2008-0581)

Smith JT, Li Q, Pereira A \& Clarke IJ 2009 Kisspeptin neurons in the ovine arcuate nucleus and preoptic area are involved in the preovulatory luteinizing hormone surge. Endocrinology 150 5530-5538. (doi:10.1210/ en.2009-0712)

Smith JT, Li Q, Yap KS, Shahab M, Roseweir AK, Millar RP \& Clarke IJ 2011 Kisspeptin is essential for the full preovulatory LH surge and stimulates $\mathrm{GnRH}$ release from the isolated ovine median eminence. Endocrinology 152 1001-1012. (doi:10.1210/en.2010-1225)

Smith JT, Reichenbach A, Lemus M, Mani BK, Zigman JM \& Andrews ZB 2013 An eGFP-expressing subpopulation of growth hormone secretagogue receptor cells are distinct from kisspeptin, tyrosine hydroxylase, and RFamide-related peptide neurons in mice. Peptides 47 45-53. (doi:10.1016/j.peptides.2013.06.012)

Stengel A, Wang L, Goebel-Stengel M \& Tache Y 2011 Centrally injected kisspeptin reduces food intake by increasing meal intervals in mice. Neuroreport 22 253-257. (doi:10.1097/WNR.0b013e32834558df)

Szymanski LA, Schneider JE, Friedman MI, Ji H, Kurose Y, Blache D, Rao A, Dunshea FR \& Clarke IJ 2007 Changes in insulin, glucose and ketone bodies, but not leptin or body fat content precede restoration of luteinising hormone secretion in ewes. Journal of Neuroendocrinology 19 449-460. (doi:10.1111/j.1365-2826.2007.01551.x)

Tariq AR, Shahab M, Clarke IJ, Pereira A, Smith JT, Khan SU, Sultan J, Javed S \& Anwar T 2013 Kiss1 and Kiss1 receptor expression in the rhesus monkey testis: a possible local regulator of testicular function. Central European Journal of Biology 8 968-974. (doi:10.2478/s11535013-0219-4)

Tena-Sempere M 2007 Roles of ghrelin and leptin in the control of reproductive function. Neuroendocrinology 86 229-241. (doi:10.1159/ 000108410)

Terao Y, Kumano S, Takatsu Y, Hattori M, Nishimura A, Ohtaki T \& Shintani Y 2004 Expression of KiSS-1, a metastasis suppressor gene, in trophoblast giant cells of the rat placenta. Biochimica et Biophysica Acta 1678 102-110. (doi:10.1016/j.bbaexp.2004.02.005)
Thomas GB, Mercer JE, Karalis T, Rao A, Cummins JT \& Clarke IJ 1990 Effect of restricted feeding on the concentrations of growth hormone $(\mathrm{GH})$, gonadotropins, and prolactin (PRL) in plasma, and on the amounts of messenger ribonucleic acid for $\mathrm{GH}$, gonadotropin subunits, and PRL in the pituitary glands of adult ovariectomized ewes. Endocrinology $\mathbf{1 2 6}$ 1361-1367. (doi:10.1210/endo-126-3-1361)

Tortoriello DV, McMinn J \& Chua SC 2004 Dietary-induced obesity and hypothalamic infertility in female DBA/2J mice. Endocrinology 145 1238-1247. (doi:10.1210/en.2003-1406)

True C, Kirigiti MA, Kievit P, Grove KL \& Smith MS 2011 Leptin is not the critical signal for kisspeptin or luteinising hormone restoration during exit from negative energy balance. Journal of Neuroendocrinology 23 1099-1112. (doi:10.1111/j.1365-2826.2011.02144.x)

True C, Verma S, Grove KL \& Smith MS 2013 Cocaine- and amphetamineregulated transcript is a potent stimulator of $\mathrm{GnRH}$ and kisspeptin cells and may contribute to negative energy balance-induced reproductive inhibition in females. Endocrinology 154 2821-2832. (doi:10.1210/ en.2013-1156)

Vikman J \& Ahren B 2009 Inhibitory effect of kisspeptins on insulin secretion from isolated mouse islets. Diabetes, Obesity \& Metabolism 11 (Suppl 4) 197-201. (doi:10.1111/j.1463-1326.2009.01116.x)

Willesen MG, Kristensen P \& Romer J 1999 Co-localization of growth hormone secretagogue receptor and NPY mRNA in the arcuate nucleus of the rat. Neuroendocrinology 70 306-316. (doi:10.1159/ 000054491)

Wu Q, Whiddon BB \& Palmiter RD 2012 Ablation of neurons expressing agouti-related protein, but not melanin concentrating hormone, in leptin-deficient mice restores metabolic functions and fertility. PNAS 109 3155-3160. (doi:10.1073/pnas.1120501109)

Xu J, Kirigiti MA, Grove KL \& Smith MS 2009 Regulation of food intake and gonadotropin-releasing hormone/luteinizing hormone during lactation: role of insulin and leptin. Endocrinology 150 4231-4240. (doi:10.1210/ en.2009-0190)

Xu Y, Nedungadi TP, Zhu L, Sobhani N, Irani BG, Davis KE, Zhang X, Zou F, Gent LM, Hahner LD et al. 2011 Distinct hypothalamic neurons mediate estrogenic effects on energy homeostasis and reproduction. Cell Metabolism 14 453-465. (doi:10.1016/j.cmet.2011.08.009)

Zigman JM, Jones JE, Lee CE, Saper CB \& Elmquist JK 2006 Expression of ghrelin receptor mRNA in the rat and the mouse brain. Journal of Comparative Neurology 494 528-548. (doi:10.1002/cne.20823)

Received 8 October 2013

First decision 5 November 2013

Revised manuscript received 25 November 2013

Accepted 10 December 2013 